\title{
Analisis dampak hukuman disiplin terhadap pencapaian key performance indicator (kpi) karyawan lembaga jaminan sosial
}

\author{
Achmad Rizki Maulana ${ }^{1}$, Euphrasia Suzy Suhendra ${ }^{2}$ \\ Lembaga Jaminan SosialUniversitas Gunadarma \\ rizkimaulana04@gmail.com ${ }^{1}$,susys@ @staff.gunadarma.ac.id ${ }^{2} \quad$ https://doi.org/10.29407/nusamba.v5i1.13837
}

Informasi Artikel

Tanggal masuk:

3 November 2019

Tanggal revisi :

24 April 2020

Tanggal diterima:

25 April 2020

\begin{abstract}
This study aims to discuss the types of violations committed by employees and the sanctions provided by social security agencies and to analyze performance outcomes before and after being given sanctions. The method used in this research is descriptive statistical analysis and different tests. The results showed that the types of violations committed by employees at the Social Security Institute include mild, moderate and severe violations with several cases, namely related to negligence leadership, procedural negligence, immoral acts, disciplinary, Fraud, Recruitment violations with sanctions starting to decrease grade, release the position , postponement of class increases for three years. The results of the sanctions indicate that there is a positive change in the sanction of achieving key performance indicators.
\end{abstract}

Keywords: Key Performance Indikator, Performance, Sanctions, Violations

\begin{abstract}
Abstrak
Penelitian ini bertujuan untuk membahas jenis pelanggaran yang dilakukan oleh karyawan dan sanksi yang diberikan oleh lembaga jaminan sosial serta melakukan analisis capaian kinerja sebelum dan sesudah diberikan sanksi. Metode yang digunakan dalam penelitian ini adalah analisis statistik deskriptif dan uji beda. Hasil penelitian menunjukkan bahwa jenis pelanggaran yang dilakukan oleh karyawan di Lembaga Jaminan Sosial ini meliputi pelanggaran ringan, sedang dan berat dengan beberapa case yaitu terkait kepemimpinan kelalaian, kelalaian prosedur, tindakan asusila, indisipliner, Fraud, Pelanggaran rekrutmen dengan sanksi mulai penurunan grade, pembebasan jabatan, penundaan kenaikan golongan selama tiga tahun. Adapun hasil dari adanya sanksi menunjukan bahwa ada perubahan positif pemberian sanksi terhadap pencapaian key performance indikator.
\end{abstract}

Kata kunci: KPI, Kinerja, Sanksi, Pelanggaran

\section{Pendahuluan}

Peranan sumber daya manusia di institusi merupakan hal yang sangat penting dan strategis guna mencapai visi dan misi institusi. Kepentingan tersebut didasari dari fungsi sumber daya manusia dalam melakukan perencanaan, pengelolaan, dan memanfaatkan

Maulana, A. R., \& Suhendra, E. S. (2020). Analisis dampak hukuman disiplin terhadap pencapaian key performance indicator (kpi) karyawan lembaga jaminan sosial. Jurnal Nusantara Aplikasi Manajemen Bisnis, 5(1), 44-55. https://doi.org/10.29407/nusamba.v5i1.13837 


\section{Jurnal Nusantara Aplikasi Manajemen Bisnis}

Vol. 5 No.1 Tahun 2020

E-ISSN : 2528-0929 P-ISSN : 2549-5291

karyawan, sehingga dapat berfungsi produktif untuk tercapainya tujuan dan cita - cita institusi.

Untuk dapat menjadi sumber daya manusia yang berkualitas institusi harus berperan aktif memajukan sumber dayanya agar sumber daya tersebut dapat melakukan inovasi untuk dapat memenangkan persaingan di zaman ini. kemajuan kemenangan tersebut hanya dapat dicapai dengan menggunakan sumber daya manusia yang berkualitas dan berdaya saing.

Agar sumber daya manusia yang dimiliki mempunyai kualitas dan daya saing, maka sangat dibutuhkan pengembangan SDM baik di bidang pengetahuan maupun keterampilan. Sifat dinamis dan selalu beradaptasi merupakan sifat alamiah manusia yang perlu terus dikembangkan. Peningkatan kinerja secara maksimal merupakan harapan dari institusi pada setiap karyawannya. Dari sifat alamiah tersebut institusi harus selalu melakukan evaluasi terhadap hal-hal yang dapat membantu pengembangan karyawan dalam rangka mencapai hasil pekerjaan yang terbaik.

Institusi menuntut seluruh karyawan dapat berperan aktif sehingga menghasilkan kinerja yang tinggi dengan tetap menjaga hak dan kewajiban dalam hubungan industrial. Sehingga mewajibkan institusi untuk membuat kesepakatan atau aturan tentang perjanian kerja bersama antara manajemen dengan karyawan yang mengatur tentang hak dan kewajiban karyawan serta manajemen sehingga memudahkan manajemen dalam melakukan pengukuran kinerja karyawan dan juga melakukan kontrol terhadap pelanggaran disiplin karyawan.

Penulis melakukan penelitian pada salah satu instansi Institusi Lembaga Jaminan Sosial berupa jasa keuangan non perbankan yang bergerak dalam bidang asuransi. Insitusi tersebut sudah berdiri lebih dari 40 tahun dengan tujuan mengedepankan hak - hak dan kepentingan masyarakat, lebih dari 4 dekade waktu yang telah dilalui oleh institusi yang artinya sudah sangat banyak pengalaman dan perkembangan yang dilakukan institusi tersebut, Peristiwa demi peristiwa dalam rangkaian perjalanan organisasi dinilai mampu melewati halangan maupun rintangan yang dihadapi.

Menyadari besar dan mulianya tanggung jawab tersebut, Institusi Lembaga Jaminan Sosial tersebut secara berkesinambungan terus meningkatkan kualitas dan kompetensi di seluruh lini, salah satunya adalah pengaturan tentang Sumber Daya Manusia, ini menjadi sangat penting untuk dapat mewujudkan visi yang dicita citakan oleh Institusi Lembaga Jaminan Sosial.

Dengan jumlah karyawan yang tergolong cukup besar di jajaran institusi pemerintah, Institusi Lembaga Jaminan Sosial membentuk peraturan - peraturan yang harus dipahami dan ditaati oleh seluruh karyawan di Institusi Lembaga Jaminan Sosial. Agar proses bisnis dapat terjaga secara governance, sesuai dengan visi dan misi Institusi Lembaga Jaminan Sosial, karenanya Institusi Lembaga Jaminan Sosial tersebut mampu membentuk karyawan yang berkualitas dan menciptakan karyawan loyalitas kepada institusi.Kinerja institusi dapat menghasilkan nilai terbaik jika karyawan dan manajemen dapat bersama - sama menjalankan peran masing - masing, untuk itu Institusi Lembaga Jaminan Sosial membuat penilaian produktifitas karyawan berdasarkan hasil kerja yang disebut dengan Key Performance Indicator (KPI), Ukuran kinerja dapat didefinisikan dalam beberapa cara. Definisi berikut ini disarankan oleh Parmenter (2017) yang dibagi atas 3 Performance Measures, Key Result Indicator (KRI), Key Performance Indicator (KPI) dan Performance Indicator (PI). Dapat dilihat pada Gambar 1.

Maulana, A. R., \& Suhendra, E. S. (2020). Analisis dampak hukuman disiplin terhadap pencapaian key performance indicator (kpi) karyawan lembaga jaminan sosial. Jurnal Nusantara Aplikasi Manajemen Bisnis, 5(1), 44-55. https://doi.org/10.29407/nusamba.v5i1.13837 


\section{Jurnal Nusantara Aplikasi Manajemen Bisnis}

Vol. 5 No.1 Tahun 2020

E-ISSN : 2528-0929 P-ISSN : 2549-5291

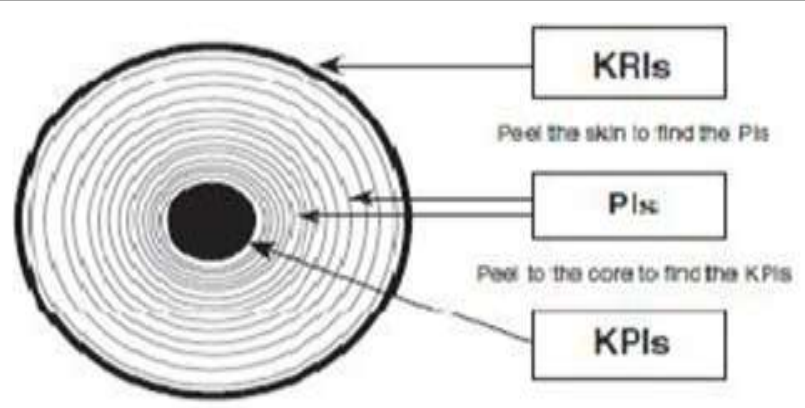

Gambar 1 Tiga Jenis Ukuran Kinerja (Parmenter 2017)

Pengukuran kinerja digunakan untuk dapat mengendalikan aspek Sumber Daya Manusia yang governance diatur dengan Peraturan Direksi Institusi Lembaga Jaminan Sosial yang disebut dengan manejemen kepegawaian.

Berdasarkan observasi yang dilakukan, peneliti melakukan observasi terhadap keputusan sanksi pelanggaran terhadap hasil penilaian kinerja karyawan, hal menarik untuk diangkat mengenai topik yang diangkat oleh penulis adalah tentang sanksi pelanggaran di Institusi Lembaga Jaminan Sosial karena dengan jumlah karyawan lebih dari 5000. Dengan kompleksitas pengelolaan karyawan tentu akan mengalami banyak potensi pelanggaran disiplin yang dilakukan karyawan sehingga disinilah urgensi dari penelitian ini. Tujuan dari penelitian ini adalah untuk mengidentifikasi serta menganalisis jenis hukuman disiplin yang berdampak pada kinerja pegawai sehingga setelah penelitian ini dilakukan dapat menjadi rujukan kebijakan yang akan dibuat oleh Lembaga Jaminan Sosial.

\section{Metode}

Penelitian ini menggunakan metode kuantitatif dan penelitian dilakukan di institusi Lembaga Jaminan Sosial dengan area penelitian di seluruh Unit Kerja Lembaga Jaminan Sosial seluruh Indonesia, data atau informasi yang didapat oleh peneliti berasal dari departemen terkait yang mengelola Sumber Daya Manusia, penelitian didasarkan pada area yang dapat dijangkau peneliti baik secara informasi formal dan informal maupun data - data yang akan dibutuhkan penulis dalam melakukan penelitian. Penelitian kualitatif adalah upaya untuk menyajikan dunia sosial, dan perspektifnya di dalam dunia, dari segi konsep, perilaku, persepsi, dan persoalan tentang manusia yang diteliti Menurut Jane Richie (dalam Moleong, 2012).

Populasi data yang diperoleh adalah menggunakan data sekunder Sumber Daya Manusia atas kasus pelanggaran dan total hasil penilaian KPI di seluruh unit kerja yang dilakukan di tahun 2016 sampai dengan 2018, adapun jenis pelanggaran antara lain Pemalsuan Data, Tindakan Asusila, Penyalahgunaan Keuangan (Fraud), Kelalaian Pengawasan, Penyalahgunaan Wewenang, Kelalaian Pengelolaan Keuangan, Kelalaian Prosedur, Pelanggaran Rekrutmen, Gaya Kepemimpinan, Pelanggaran Prosedur Klaim, Kelalaian Melaksanakan Tugas Dan Tanggung Jawab, dan Indisipliner. Menurut Sugiyono (2012) Populasi adalah wilayah generalisasi yang terdiri atas; obyek/subyek mempunyai

Maulana, A. R., \& Suhendra, E. S. (2020). Analisis dampak hukuman disiplin terhadap pencapaian key performance indicator (kpi) karyawan lembaga jaminan sosial. Jurnal Nusantara Aplikasi Manajemen Bisnis, 5(1), 44-55. https://doi.org/10.29407/nusamba.v5i1.13837 


\section{Jurnal Nusantara Aplikasi Manajemen Bisnis}

Vol. 5 No.1 Tahun 2020

E-ISSN : 2528-0929 P-ISSN : 2549-5291

kuantitas dan karakteristik tertentu yang ditetapkan oleh peneliti untuk dipelajari dan kemudian ditarik kesimpulannya.

Untuk melihat perbedaan nilai rata - rata pada dua atau beberapa sampel yang tidak berhubungan dapat dilakukan dengan menggunakan uji beda atau t-test. Uji beda dilakukan untuk mengetahui apakah kelompok data tersebut memiliki rata - rata yang sama atau tidak. Uji beda $\mathrm{t}$ yang digunakan dalam penelitian ini adalah uji t dengan dua sampel bebas. Menurut Widiyanto (2013) Paired sample t-test merupakan salah satu metode pengujian yang digunakan untuk mengkaji keefektifan perlakuan ditandai adanya perbedaan rata - rata sebelum dan sesudah diberikan perlakuan.

Uji beda t-test digunakan untuk menentukan apakah dua sampel yang tidak berhubungan memiliki nilai rata-rata yang berbeda. Uji beda t-test dilakukan dengan cara membandingkan perbedaan antara dua nilai rata-rata dengan standart error dari perbedaan rata-rata dua sampel atau dapat ditulis dengan rumus sebagai berikut :

Standar error perbedaan dalam nilai rata-rata terdistribusi secara normal. Dapat disimpulkan bahwa uji beda t-test adalah membandingkan rata-rata dua grup yang tidak berhubungan satu dengan yang lainnya

\section{Hasil dan Pembahasan}

Berdasarkan data Sekunder Lembaga Jaminan Sosial tahun 2019 terdapat pelanggaran disiplin karyawan yang mendapatkan hukuman periode bulan maret di tahun 2016, 2017 dan 2018 adalah sebagai berikut, Unit Kerja Cabang Bali Gianyar sebanyak 1 karyawan, Unit Kerja Cabang Banda Aceh sebanyak 3 karyawan, Unit Kerja Cabang Banjarmasin sebanyak 3 karyawan, Unit Kerja Cabang Bengkulu sebanyak 1 karyawan, Unit Kerja Cabang Bogor Kota sebanyak 1 karyawan, Unit Kerja Cabang Ceger sebanyak 1 karyawan, Unit Kerja Cabang Cilincing sebanyak 2 karyawan, Unit Kerja Cabang Duri sebanyak 2 karyawan, Unit Kerja Cabang Grogol sebanyak 4 karyawan, Unit Kerja Cabang Jakarta Salemba sebanyak 1 karyawan, Unit Kerja Cabang Klaten sebanyak 1 karyawan, Unit Kerja Cabang Medan Kota sebanyak 1 karyawan, Unit Kerja Cabang Mimika sebanyak 2 karyawan, Unit Kerja Cabang Palembang sebanyak 1 karyawan, Unit Kerja Cabang Palu sebanyak 2 karyawan, Unit Kerja Cabang Semarang Pemuda sebanyak 1 karyawan, Unit Kerja Cabang Serang sebanyak 1 karyawan, Unit Kerja Cabang Ungaran sebanyak 1 karyawan, Unit Kerja Wilayah Jawa Barat sebanyak 1 karyawan, Unit Kerja Cabang Pembantu Bantul sebanyak 1 karyawan, Unit Kerja Cabang Pembantu Mamuju Utara sebanyak 1 karyawan, Unit Kerja Cabang Pembantu Tanjung Jabung Barat Kuala Tungkal sebanyak 3 karyawan.

Maulana, A. R., \& Suhendra, E. S. (2020). Analisis dampak hukuman disiplin terhadap pencapaian key performance indicator (kpi) karyawan lembaga jaminan sosial. Jurnal Nusantara Aplikasi Manajemen Bisnis, 5(1), 44-55. https://doi.org/10.29407/nusamba.v5i1.13837 


\section{Jurnal Nusantara Aplikasi Manajemen Bisnis}

Vol. 5 No.1 Tahun 2020

E-ISSN : 2528-0929 P-ISSN : 2549-5291

\section{Jenis Dan Bentuk Hukuman Dan Pelanggaran Disiplin Ringan, Sedang Dan Berat :}

1) Pelanggaran Disiplin Ringan

1.1 ) Jenis Hukuman Disiplin Ringan :
a. Teguran Lisan Tercatat.
b. Surat Peringatan Pertama.
c. Surat Peringatan Kedua (Terakhir)

1.2 ) Jenis Pelanggaran Disiplin Ringan :

a. Datang terlambat 5 (lima) kali atau pulang lebih awal 5 (lima) kali atau gabungan keduanya 5 (lima) kali dalam kurun waktu 1 (satu) bulan.

b. Lalai mengikuti ketentuan tentang jam kerja, datang terlambat atau meninggalkan tempat kerja lebih cepat dari pada waktu yang ditentukan, tanpa terlebih dahulu mendapat izin atau persetujuan atasan yang berwenang.

c. Tidak hadir bekerja tanpa alasan yang dapat diterima atau tanpa terlebih dahulu mendapat izin dari atasan yang berwenang selama 1 (satu) hari.

d. Membawa peralatan kerja, data / dokumen atau harta milik Lembaga Jaminan Sosial lainnya keluar dari Lembaga Jaminan Sosial kecuali telah mendapat izin dari atasannya atau pejabat Lembaga Jaminan Sosial yang berwenang.

e. Melalaikan tugas dan kewajiban yang diberikan.

2) Pelanggaran Disiplin Sedang

2.1 ) Jenis Hukuman Disiplin Sedang :

a. Penundaan kenaikan gaji berkala selama 1 (satu) tahun.

b. Penundaan kenaikan golongan selama 1 (satu) tahun.

c. Penundaan kenaikan golongan selama 2 (dua) tahun.

d. Penurunan grade 1 (satu) tingkat selama 2 (dua) tahun.

e. Penurunan grade 2 (dua) tingkat selama 2 (dua) tahun.

f. Pembebasan dari jabatan struktural.

2.2 ) Jenis Pelanggaran Disiplin Sedang :

a. Dengan sengaja dan tidak semestinya meminta dan/atau mencatatkan kehadiran Karyawan.

b. Menolak untuk melaksanakan perintah yang layak yang diberikan oleh Pejabat yang berwenang untuk itu sesuai dengan tugas dan tanggung jawab pekerjaannya.

c. Atasan yang memberikan izin dan bawahan yang meminta izin untuk tidak masuk kerja 3 kali dalam 1 (satu) bulan, kecuali kepentingan dinas. 


\section{Jurnal Nusantara Aplikasi Manajemen Bisnis}

Vol. 5 No.1 Tahun 2020

E-ISSN : 2528-0929 P-ISSN : 2549-5291

d. Menerima hadiah atau suatu pemberian berupa apa saja dari siapapun juga yang diketahui atau patut diduga bahwa pemberian itu berkaitan dengan jabatan atau pekerjaan Karyawan bersangkutan.

e. Memasuki tempat yang dapat mencemarkan kehormatan dan martabat Karyawan dan Lembaga Jaminan Sosial kecuali untuk kepentingan dinas.

f. Membuat keonaran/kerusuhan, perbuatan yang meresahkan dalam lingkungan kerja.

g. Kelalaian dalam mengelola dana Lembaga Jaminan Sosial yang mengakibatkan kerugian bagi Lembaga Jaminan Sosial.

h. Melakukan perbuatan yang bertentangan dengan norma-norma yang berlaku di masyarakat yang dapat menurunkan citra, kehormatan, dan martabat Lembaga Jaminan Sosial.

3) Pelanggaran Disiplin Berat

3.1 ) Jenis Hukuman Disiplin Berat :

a. Penundaan kenaikan golongan selama 3 (tiga) tahun.

b. Penurunan grade 2 (dua) tingkat dengan masa hukuman selama 3 (tiga) tahun.

c. Penurunan grade 2 (dua) tingkat dengan masa hukuman selama 3 (tiga) tahun dan penundaan kenaikan golongan selama 3 (tiga) tahun.

d. Penurunan grade 2 (dua) tingkat dengan masa hukuman selama 3 (tiga) tahun, pembebasan jabatan struktural dan penundaan kenaikan golongan selama 3 (tiga) tahun.

3.2 ) Jenis Pelanggaran Disiplin Berat:

a. Melakukan penipuan, pencurian atau penggelapan barang dan/atau uang milik Lembaga Jaminan Sosial.

b. Mabuk, meminum minuman keras yang memabukkan dilingkungan kerja.

c. Memakai, mengedarkan narkotika, psikotropika dan zat adiktif lainnya di lingkungan kerja maupun diluar lingkungan kerja.

d. Melakukan perjudian dilingkungan kerja maupun di luar lingkungan kerja.

e. Melakukan pelecehan seksual, asusila dan tindakan pornografi di lingkungan kerja.

f. Melakukan segala macam bentuk perilaku pendekatan-pendekatan yang terkait dengan seks yang tidak diinginkan, termasuk permintaan untuk melakukan seks dan perilaku lainnya yang secara verbal ataupun fisik merujuk pada seks di dalam lingkungan kerja.

g. Hidup bersama diluar nikah, memiliki hubungan terlarang yang salah satu atau keduanya sudah menikah, hamil diluar nikah atau mempunyai anak diluar nikah. 


\section{Jurnal Nusantara Aplikasi Manajemen Bisnis}

Vol. 5 No.1 Tahun 2020

E-ISSN : 2528-0929 P-ISSN : 2549-5291

h. Membujuk teman sekerja atau atasan untuk melakukan perbuatan yang bertentangan dengan peraturan perundang-undangan.

i. Membongkar atau membocorkan dokumen rahasia Lembaga Jaminan Sosial yang seharusnya dirahasiakan kecuali untuk kepentingan Negara.

j. Menyalahgunakan wewenang yang merugikan Lembaga Jaminan Sosial secara materiil untuk kepentingan diri sendiri.

k. Melakukan pungutan tidak sah dalam bentuk apapun juga pada waktu melaksanakan tugasnya untuk kepentingan pribadi, golongan atau pihak lain.

1. Menyalahgunakan keuangan Lembaga Jaminan Sosial.

m. Tidak masuk bekerja tanpa keterangan (alpa) sebanyak 10 (sepuluh) hari kerja selama kurun waktu 6 (enam) bulan.

\section{Uji Beda}

\section{Uji Beda Pada Pelanggaran Disiplin Ringan}

Jumlah pelanggaran dengan disiplin ringan adalah sebanyak 10 orang atau $27.8 \%$ dari total seluruhnya 36 orang yang melakukan pelanggaran. Analisis terhadap pelanggaran disiplin ringan terhadap pencapaian nilai KPI adalah sebagai berikut :

Tabel 1. KPI Karyawan Pelanggaran Disiplin Ringan

\begin{tabular}{|rclccr|}
\hline No & Nama & Status Case & $\begin{array}{c}\text { Kpi } \\
\text { Sebelum }\end{array}$ & $\begin{array}{c}\text { Kpi } \\
\text { Sesudah }\end{array}$ & Persentase \\
\hline 1 & Karyawan 9 & Pelanggaran Disiplin Ringan & 4.32 & 4.96 & 114,81 \\
\hline 2 & Karyawan 12 & Pelanggaran Disiplin Ringan & 4.30 & 4.86 & 113,02 \\
\hline 3 & Karyawan 16 & Pelanggaran Disiplin Ringan & 4.10 & 4.88 & 119,02 \\
\hline 4 & Karyawan 18 & Pelanggaran Disiplin Ringan & 5.08 & 5.51 & 108,46 \\
\hline 5 & Karyawan 19 & Pelanggaran Disiplin Ringan & 4.63 & 5.80 & 125,27 \\
\hline 6 & Karyawan 20 & Pelanggaran Disiplin Ringan & 4.41 & 4.39 & 99,55 \\
\hline 7 & Karyawan 24 & Pelanggaran Disiplin Ringan & 5.15 & 5.80 & 112,62 \\
\hline 8 & Karyawan 28 & Pelanggaran Disiplin Ringan & 2.60 & 4.51 & 173,46 \\
\hline 9 & Karyawan 29 & Pelanggaran Disiplin Ringan & 5.23 & 4.91 & 93,88 \\
\hline 10 & Karyawan 30 & Pelanggaran Disiplin Ringan & 4.09 & 4.03 & 98,53 \\
\hline
\end{tabular}

Data hasil uji beda pada pelanggaran disiplin ringan dimana hasil perhitungan ini akan menggambarkan sejauh mana efektifitas hukuman yang diberikan terhadap nilai KPI. 
Tabel 2. Uji Beda Pelanggaran Disiplin Ringan

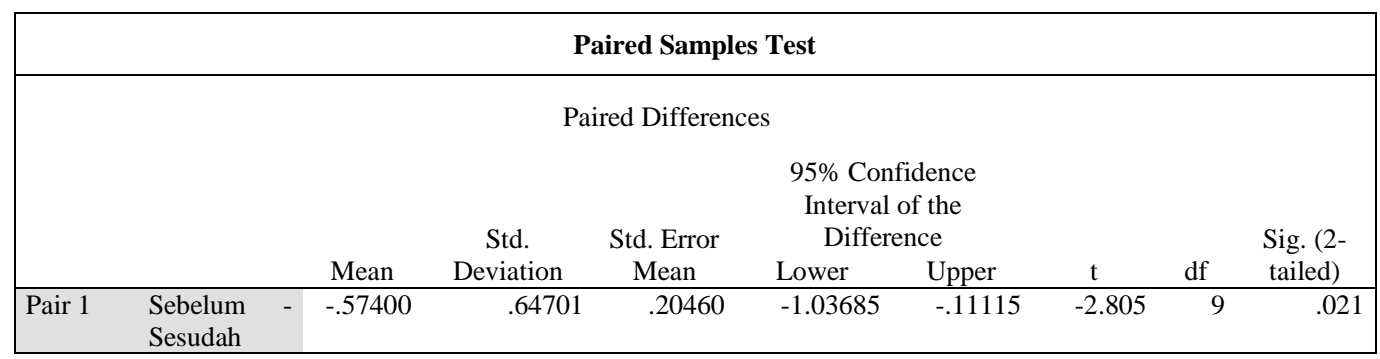

Tabel Paired Samples Test di atas dapat kita ketahui bahwa sig. (2-tailed) adalah 0.021 . Hal ini berarti nilainya lebih kecil dari 0.05 atau 5\% / $(?=5 \%)$ dari margin error yang ditentukan. Karena nilai signifikan dibawah 0,05 maka dapat dikatakan pemberian hukuman pada pelaku pelanggaran disiplin ringan berdampak signifikan terhadap perubahan nilai KPI.

Dari tabel tersebut dapat kita ketahui pula hukuman memberikan perubahan terhadap Nilai KPI tersebut $-0,57400$ karena mean negatif maka dapat diartikan dalam kondisi yang sebenarnya pemberian hukuman yang dijatuhkan dalam pelanggaran disiplin ringan dapat berdampak positif meningkatkan KPI sebesar 0,57400 . hal ini terbukti dari 10 orang yang dijatuhi hukuman 8 orang diantaranya mengalami kenaikan Nilai KPI ditahun berikutnya setelah dijatuhi hukuman sedangkan 2 orang hukuman yang diberikan justru berdampak negatif atau menurunkan nilai KPI. Sehingga hal ini memperkuat hipotesis penulis yaitu terdapat hubungan yang signifikan antara penjatuhan hukuman atau hukuman pelaku pelanggar disiplin terhadap capaian KPI nya dari sebelum dijatuhkan hukuman hukuman

\section{Uji Beda Pada Pelanggaran Disiplin Sedang}

Jumlah pelanggaran dengan disiplin sedang adalah sebanyak 15 orang atau $41.6 \%$ dari total seluruhnya 36 orang yang melakukan pelanggaran. Analisis terhadap pelanggaran disiplin sedang terhadap pencapaian nilai KPI adalah sebagai berikut :

Tabel 3. KPI Karyawan Pelanggaran Disiplin Sedang

\begin{tabular}{|cccccc|}
\hline No & Nama & Status Case & $\begin{array}{c}\text { Kpi } \\
\text { Sebelum }\end{array}$ & $\begin{array}{c}\text { Kpi } \\
\text { Sesudah }\end{array}$ & Persentase \\
\hline 1 & Karyawan 3 & Pelanggaran Disiplin Sedang & 3.46 & 5.01 & 144,80 \\
\hline 2 & Karyawan 4 & Pelanggaran Disiplin Sedang & 4.38 & 4.17 & 95,21 \\
\hline 3 & Karyawan 5 & Pelanggaran Disiplin Sedang & 4.31 & 4.81 & 111,60 \\
\hline 4 & Karyawan 11 & Pelanggaran Disiplin Sedang & 5.12 & 4.95 & 96,68 \\
\hline
\end{tabular}

Maulana, A. R., \& Suhendra, E. S. (2020). Analisis dampak hukuman disiplin terhadap pencapaian key performance indicator (kpi) karyawan lembaga jaminan sosial. Jurnal Nusantara Aplikasi Manajemen Bisnis, 5(1), 44-55. https://doi.org/10.29407/nusamba.v5i1.13837 


\section{Jurnal Nusantara Aplikasi Manajemen Bisnis}

Vol. 5 No.1 Tahun 2020

E-ISSN : 2528-0929 P-ISSN : 2549-5291

\begin{tabular}{|cccccc|}
\hline No & Nama & Status Case & $\begin{array}{c}\text { Kpi } \\
\text { Sebelum }\end{array}$ & $\begin{array}{c}\text { Kpi } \\
\text { Sesudah }\end{array}$ & Persentase \\
\hline 5 & Karyawan 13 & Pelanggaran Disiplin Sedang & 4.66 & 5.11 & 109,66 \\
\hline 6 & Karyawan 14 & Pelanggaran Disiplin Sedang & 4.72 & 5.42 & 114,83 \\
\hline 7 & Karyawan 15 & Pelanggaran Disiplin Sedang & 4.74 & 5.45 & 114,98 \\
\hline 8 & Karyawan 21 & Pelanggaran Disiplin Sedang & 4.75 & 5.35 & 112,63 \\
\hline 9 & Karyawan 22 & Pelanggaran Disiplin Sedang & 4.77 & 5.43 & 113,84 \\
\hline 10 & Karyawan 23 & Pelanggaran Disiplin Sedang & 4.78 & 5.55 & 116,11 \\
\hline 11 & Karyawan 31 & Pelanggaran Disiplin Sedang & 5.02 & 5.71 & 113,75 \\
\hline 12 & Karyawan 32 & Pelanggaran Disiplin Sedang & 5.74 & 5.52 & 96,17 \\
\hline 13 & Karyawan 34 & Pelanggaran Disiplin Sedang & 4.47 & 5.21 & 116,55 \\
\hline 14 & Karyawan 35 & Pelanggaran Disiplin Sedang & 5.00 & 4.91 & 98,20 \\
\hline 15 & Karyawan 36 & Pelanggaran Disiplin Sedang & 5.09 & 4.98 & 97,84 \\
\hline
\end{tabular}

Data hasil uji beda pada pelanggaran disiplin sedang dimana hasil perhitungan ini akan menggambarkan sejauh mana efektifitas hukuman yang diberikan terhadap nilai KPI.

Tabel 4. Uji Beda Pada Pelanggaran Disiplin Sedang

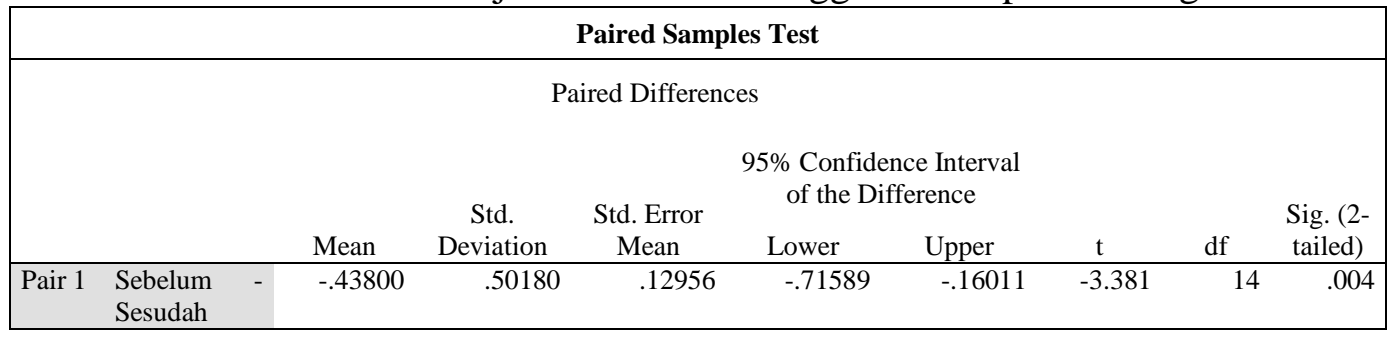

Tabel Paired Samples Test di atas dapat kita ketahui bahwa sig. (2-tailed) adalah 0.004. Hal ini berarti nilainya lebih dari 0.05 atau 5\% / $(?=5 \%)$ dari margin error yang ditentukan. Sehingga dapat dikatakan penjatuhan hukuman atau hukuman berdampak signifikan terhadap perubahan pencapaian nilai KPI. Dari tabel tersebut dapat kita ketahui pula hukuman memberikan perubahan terhadap Nilai KPI tersebut $-0,43800$ karena mean negatif maka dapat diartikan dalam kondisi yang sebenarnya pemberian hukuman yang dijatuhkan dalam pelanggaran disiplin sedang dapat berdampak positif meningkatkan KPI sebesar 0,43800. hal ini terbukti dari 15 orang yang dijatuhi hukuman, 10 orang diantaranya mengalami kenaikan Nilai KPI ditahun berikutnya setelah dijatuhi hukuman sedangkan 5 orang hukuman yang diberikan justru berdampak negatif atau menurunkan nilai KPI. Selain itu hasil ini mendukung pernyataan hipotesis penulis yaitu pemberian hukuman akan berdampak positif terhadap pencapaian nilai KPI.

Maulana, A. R., \& Suhendra, E. S. (2020). Analisis dampak hukuman disiplin terhadap pencapaian key performance indicator (kpi) karyawan lembaga jaminan sosial. Jurnal Nusantara Aplikasi Manajemen Bisnis, 5(1), 44-55. https://doi.org/10.29407/nusamba.v5i1.13837 
Jurnal Nusantara Aplikasi Manajemen Bisnis

Vol. 5 No.1 Tahun 2020

E-ISSN : 2528-0929 P-ISSN : 2549-5291

\section{Uji Beda Pada Pelanggaran Disiplin Berat}

Jumlah pelanggaran dengan disiplin berat adalah sebanyak 11 orang atau $30.6 \%$ dari total seluruhnya 36 orang yang melakukan pelanggaran. Analisis terhadap pelanggaran disiplin berat terhadap pencapaian nilai KPI adalah sebagai berikut :

Tabel 5. KPI Karyawan Pelanggaran Disiplin Berat

\begin{tabular}{|cccccr|}
\hline No & Nama & Status Case & $\begin{array}{c}\text { Kpi } \\
\text { Sebelum }\end{array}$ & $\begin{array}{c}\text { Kpi } \\
\text { Sesudah }\end{array}$ & Persentase \\
\hline 1 & Karyawan 1 & Pelanggaran Disiplin Berat & 4.05 & 4.78 & 118,02 \\
\hline 2 & Karyawan 2 & Pelanggaran Disiplin Berat & 4.13 & 4.45 & 107,75 \\
\hline 3 & Karyawan 6 & Pelanggaran Disiplin Berat & 5.21 & 5.18 & 99,42 \\
\hline 4 & Karyawan 7 & Pelanggaran Disiplin Berat & 4.82 & 5.41 & 112,24 \\
\hline 5 & Karyawan 8 & Pelanggaran Disiplin Berat & 5.36 & 5.30 & 98,88 \\
\hline 6 & Karyawan 10 & Pelanggaran Disiplin Berat & 4.74 & 5.38 & 113,50 \\
\hline 7 & Karyawan 17 & Pelanggaran Disiplin Berat & 5.21 & 5.19 & 99,62 \\
\hline 8 & Karyawan 25 & Pelanggaran Disiplin Berat & 4.52 & 4.95 & 109,51 \\
\hline 9 & Karyawan 26 & Pelanggaran Disiplin Berat & 5.22 & 5.2 & 99,62 \\
\hline 10 & Karyawan 27 & Pelanggaran Disiplin Berat & 5.10 & 4.98 & 97,65 \\
\hline 11 & Baryawan 33 & Pelanggaran Disiplin Berat & 4.51 & 5.18 & 114,86 \\
\hline
\end{tabular}

ta hasil uji beda pada pelanggaran disiplin berat dimana hasil perhitungan ini akan menggambarkan sejauh mana efektifitas hukuman yang diberikan terhadap nilai KPI.

Tabel 6. Uji Beda Pelanggaran Disiplin Berat

\begin{tabular}{|c|c|c|c|c|c|c|c|c|c|}
\hline \multicolumn{10}{|c|}{ Paired Samples Test } \\
\hline \multirow{3}{*}{\multicolumn{3}{|c|}{ Mean }} & \multirow{2}{*}{\multicolumn{4}{|c|}{$\begin{array}{l}\text { 95\% Confidence Interval of } \\
\text { the Difference }\end{array}$}} & \multirow[b]{3}{*}{$\mathrm{t}$} & \multirow[b]{3}{*}{$\mathrm{df}$} & \multirow[b]{3}{*}{$\begin{array}{l}\text { Sig. }(2- \\
\text { tailed) }\end{array}$} \\
\hline & & & & & & & & & \\
\hline & & & $\begin{array}{c}\text { Std. } \\
\text { Deviation }\end{array}$ & $\begin{array}{l}\text { Std. Error } \\
\text { Mean }\end{array}$ & Lower & Upper & & & \\
\hline $\begin{array}{ll}\text { Pair 1 } & \begin{array}{l}\text { Sebelum } \\
\text { Sesudah }\end{array} \\
\end{array}$ & - & -.28455 & .33998 & .10251 & -.51295 & -.05614 & -2.776 & 10 & .020 \\
\hline
\end{tabular}

Maulana, A. R., \& Suhendra, E. S. (2020). Analisis dampak hukuman disiplin terhadap pencapaian key performance indicator (kpi) karyawan lembaga jaminan sosial. Jurnal Nusantara Aplikasi Manajemen Bisnis, 5(1), 44-55. https://doi.org/10.29407/nusamba.v5i1.13837 


\section{Jurnal Nusantara Aplikasi Manajemen Bisnis}

Vol. 5 No.1 Tahun 2020

E-ISSN : 2528-0929 P-ISSN : 2549-5291

Tabel Paired Samples Test di atas dapat kita ketahui bahwa sig. (2-tailed) adalah 0.020. Hal ini berarti nilainya lebih kecil dari 0.05 atau 5\% / $(?=5 \%)$ dari margin error yang ditentukan. Sehingga dapat dikatakan penjatuhan hukuman atau hukuman berdampak signifikan terhadap perubahan pencapaian nilai KPI. Dari tabel tersebut dapat kita ketahui pula hukuman memberikan perubahan terhadap Nilai KPI tersebut sebesar -0,28455 karena mean bersifat negatif maka artinya dalam kondisi yang sebenarnya pemberian hukuman akan meningkatkan capaian KPI sebesar 0,28455 artinya hukuman yang dijatuhkan kepada pelaku pelanggaran disiplin berat akan berdampak positif terhadap perubahan KPI hal ini berarti hukuman yang diberikan bersifat positif artinya ketika karyawan mendapatkan hukuman dalam dirinya ada keinginan yang kuat untuk berubah sehingga nilai capaian KPI menjadi meningkat.

\section{Pembahasan}

Kinerja merupakan suatu hal yang sangat penting dalam sebuah organisasi. Untuk mencapai kinerja yang prima banyak hal yang perlu diperhatikan salah satunya adalah aspek punishment atau sanksi dimana dalam sebuah organisasi pasti tidak akan pernah terlepas dari pelanggaran-pelanggaran yang dilakukan oleh seorang pegawai sehingga dalam perjalanannya perlu ditegakan sanksi yang bersifat mendidik dan mampu memberikan efek jera terhadap perilaku pegawai. Dengan adanya sanksi yang baik setiap pelanggaran akan dapat ditekan. Hal ini dikuatkan oleh hasil penelitian ini yang menunjukan adanya perbedaan kinerja sebelum dan sesudah pemberian sanksi serta adanya dampak positif dari pemberian sanksi terhadap kinerja.

\section{Kesimpulan}

Hasil dari penelitian menunjukan bahwa Jenis hukuman yang diberikan kepada karyawan yang melakukan pelanggaran disiplinan ringan, sedang dan berat menunjukan bahwa pada umumnya pemberian hukuman terhadap karyawan yang melakukan permasalahan / kasus memberikan dampak positif atau meningkatkan nilai kinerja atau Key Performance Indicator. Semua jenis hukuman yang diberikan kepada para karyawan dapat memberikan dampak positif yang artinya hukuman yang diberikan memberikan dorongan kepada para karyawan untuk bekerja lebih baik dan memberikan perubahan yang signifikan terhadap capaian nilai Key Performance Indicator dari sebelum mendapat hukuman dan setelah diberikan hukuman.

\section{DAFTAR PUSTAKA}

Wahyuningrum. (2008). Hubungan Kemampuan, kepuasan dan disiplin kerja dengan kinerja pegawai di kecamatan tanggungharjo kabupaten grobogan. Tesis (S2) Magister Ilmu Administrasi Universitas Diponegoro Semarang.

Mahsun. (2013). Metode penelitian Bahasa : Tahapan Strategi, Metode, dan Tekniknya, Jakarta : Rajagrafindo Persada.

Sarwono. (2015). Pengantar Umum Pendidikan, Jakarta : Rineka Cipta.

Maulana, A. R., \& Suhendra, E. S. (2020). Analisis dampak hukuman disiplin terhadap pencapaian key performance indicator (kpi) karyawan lembaga jaminan sosial. Jurnal Nusantara Aplikasi Manajemen Bisnis, 5(1), 44-55. https://doi.org/10.29407/nusamba.v5i1.13837 
Jurnal Nusantara Aplikasi Manajemen Bisnis

Vol. 5 No.1 Tahun 2020

E-ISSN : 2528-0929 P-ISSN : 2549-5291

Moleong, Jane Richie. 2012. Metodologi Penelitian Kualitatif : Edisi Revisi. Bandung : PT. Remaja Rosdakarya.

Widiyanto, M.A. (2013). Statistika Terapan, Konsep dan Aplikasi SPSS/Lisrel Dalam penelitian Pendidikan, Psikologi dan Ilmu Sosial lainnya. Jakarta : PT. Elex Media Komputindo.

Sugiyono. (2012). Metodologi Penelitian Kuantitatif, Kualitatif dan R\&D. Bandung : CV. Alfabeta. 